\title{
Lap Cholecystectomy After Acute Gallstone Pancreatitis - Experience of Six Cases
}

\author{
K M Garg ${ }^{1}$, Manish Kumar Gupta ${ }^{2}$ \\ ${ }^{1}$ Professor \& HOD, Dept Of General Surgery, JNU IMSRC, Jaipur. \\ ${ }^{2}$ Asst Professor, Dept Of General Surgery, JNU IMSRC, Jaipur.
}

\begin{abstract}
To study the safety of cholecystectomy during the index admission following acute gall stone pancreatitis. Six patients of cholecysto-pancreatitis underwent Lap cholecystectomy during 1 year period w.e.f. oct 2015 to sept. 2016. Initial two cases underwent interval cholecystectomy (IC), while subsequent 4 cases early cholecystectomy (EC). There was no conversion or bile duct injury. Early cholecystectomy following acute gallstone pancreatitis was found to be a safe procedure when performed during index admission.
\end{abstract}

Keywords: Gallstone pancreatitis, Early cholecystectomy, Interval cholecystectomy.

\section{Introduction}

Gall stone and biliary sludge accounted for $30-55 \%$ of acute pancreatitis in the west ${ }^{(1)}$. The risk of subsequent attacks for patient recovering from the first attack of acute gallstone pancreatitis is 30 fold higher than general population ${ }^{(2)}$. Further attacks can be prevented by cholecystectomy and bile duct stone clearance once the acute stage of the disease has settled. However the optimal timing of cholecystectomy after gallstone pancreatitis remains unclear.Herein we present our experience of treating six such cases.

\section{Material And Methods}

In this prospective study, medical record of patients admitted with a diagnosis of acute gallstone pancreatitis between oct 2015 to sept. 2016 were maintained. The diagnosis of mild acute gallstone pancreatitis was based on the presence of upper abdominal pain, a serum amylase level of $>500 \mathrm{U} / \mathrm{L}(25-115 \mathrm{U} / \mathrm{L}),<3$ Ranson's score ${ }^{(3,4)}$ and the presence of gallstone on the transabdominal ultrasonography. medical record of age, gender, presenting symptoms, laboratory findings, imaging studies, course, time between resolution of acute pancreatitis and cholecystectomy, intra-operative findings, biliary injury, intra-operative bleeding, conversion to open surgery, duration of operation, experience of operating surgeon, length of hospital stay, outpatient follow up , recurrent gallstone related events and outcome was noted.

The initial management included nil orally, fluids and electrolyte replacement, analgesia, oxygen administration and naso- gastric intubation if necessary. Oral feeding was introduced on clinical improvement and decline in serum amylase level. First two patients were discharged for IC, were readmitted at the appointed time for Laparoscopic cholecystectomy. Subsequent four Patients underwent Laparoscopic cholecystectomy in the index admission, once Pancreatitis got settled and liver functions were on declining trend. After discharge from hospital, all patients were followed up in the outpatient department (OPD) with an average of 2-4 OPD visits over 3-6 months till they remain completely asymptomatic. We defined EC as Lap cholecystectomy during index hospital admission for acute Pancreatitis, while IC was defined as lap cholecystectomy during a planned new hospitalization after initial conservative treatment of acute gallstone Pancreatitis.

\section{Results}

During study period (oct 2015 to sept 2016), six patients were admitted with a diagnosis of acute gallstone pancreatitis. The mean age was 53.1 year. Two patients were male and four were female. The most common symptom at presentation was pain upper abdomen (100\%), followed by vomiting (82\%), fever (50\%) and jaundice (33\%).Diagnosis was made on basis of clinical presentation, serum amylase, serum lipase, ultrasonography, SGOT, SGPT, Serum alkaline phosphatase and computerized tomography (CT) scan. Serum amylase was raised in 50\% cases (more than three fold in 33\%). Ultrasonography revealed cholelithiasis in all the 6 patients. CT scan was done in all six patients and had Balthazar CT severity index of four or more.

All the patients were treated with conservative management. Initial two patients were discharged from hospital and called for IC at 6 weeks after. The subsequent 4 patients underwent cholecystectomy in the same admission had uneventful recovery without any complication. 


\begin{tabular}{|c|c|c|c|c|c|c|c|}
\hline \multicolumn{8}{|c|}{ Operative details: } \\
\hline $\begin{array}{l}\text { S. } \\
\text { N. }\end{array}$ & $\begin{array}{l}\text { Age/ } \\
\text { Sex }\end{array}$ & $\begin{array}{l}\text { Pneumo } \\
\text { creation }\end{array}$ & $\begin{array}{l}\text { Plasterin } \\
\text { g of } \\
\text { porta }\end{array}$ & Oozing & $\begin{array}{l}\text { Operati } \\
\text { ng time }\end{array}$ & Specific & Tips \\
\hline 1. & $42 / \mathrm{F}$ & - & Present & Present & $2 \mathrm{hrs}$ & Firm adhesions & - \\
\hline 2. & $48 / \mathrm{M}$ & - & Minimal & No ooze & $2 \mathrm{hrs}$ & No adhesion & - \\
\hline 3. & $56 / \mathrm{M}$ & $\begin{array}{l}\text { Palmer's } \\
\text { point }\end{array}$ & Present & $\begin{array}{l}\text { More } \\
\text { oozing }\end{array}$ & $2 \mathrm{hrs}$ & $\begin{array}{l}\text { Omental adhesion } \\
\text { to diaphragmatic } \\
\text { surface }\end{array}$ & $\begin{array}{ll}\text { *Suction } & \text { tip } \\
\text { dissection } & \\
\text { *Rouviere's } & \\
\text { sulcus guide } & \\
\end{array}$ \\
\hline 4. & $65 / \mathrm{M}$ & $\begin{array}{l}\text { Umbilical } \\
\text { port }\end{array}$ & Minimal & - & $\begin{array}{l}1 \mathrm{hrs} 30 \\
\min \end{array}$ & $\begin{array}{lr}\text { GB encased by } \\
\text { omentum } & \text { and } \\
\text { duodenal } & \\
\text { adhesions } & \end{array}$ & $\begin{array}{l}\text { *Rouviere's } \\
\text { sulcus safe } \\
\text { dissection guide }\end{array}$ \\
\hline 5. & $50 / \mathrm{F}$ & $\begin{array}{l}\text { Umbilical } \\
\text { port }\end{array}$ & Present & $\begin{array}{l}\text { More } \\
\text { oozing }\end{array}$ & $\begin{array}{l}2 \text { hrs } 15 \\
\min \end{array}$ & $\begin{array}{l}\text { saponification all } \\
\text { over omentum and } \\
\text { peritoneal surface }\end{array}$ & $\begin{array}{ll}* \text { Suction } & \text { tip } \\
\text { dissection } & \text { for } \\
\text { adhesions } & \\
\text { *Rouviere's } & \\
\text { sulcus guide } & \\
\end{array}$ \\
\hline 6. & $58 / \mathrm{F}$ & $\begin{array}{l}\text { Umbilical } \\
\text { port }\end{array}$ & Present & $\begin{array}{l}\text { More } \\
\text { oozing }\end{array}$ & $2 \mathrm{hrs}$ & $\begin{array}{l}\text { GB hidden and } \\
\text { plastering present }\end{array}$ & $\begin{array}{ll}\text { *Suction } & \text { tip } \\
\text { dissection } & \\
\text { *Rouviere's } & \\
\text { sulcus guide } & \end{array}$ \\
\hline
\end{tabular}

Table 1: Showing operative details of cases of gallstone pancreatitis

Table 1 shows overall details of cases. None of our case converted to open surgery. The main reason for conversion to open surgery in the early cholecystectomy cases has been the friable and oedematous gall bladder, which tore when grasped and in the delayed group the main reason for conversion was difficulty in gall bladder exposure and dense adhesion obscuring the anatomy of calot's triangle ${ }^{(5)}$. The mean operating time in early group was 104 minutes while that in IC group was 90minutes.The mean intra-operative blood loss in the early group was $240 \mathrm{ml}$, where as that in the delayed group was only $100 \mathrm{ml}^{(5)}$.

The adhesion of colon to anterior abdominal wall (shown Fig 3) was separated by metal suction tip medial to lateral swipe adjacent to anterior abdominal wall and this manoeuvre led to view of upper compartment of abdomen easily. Tissues overall were very vascular (shown Fig 4), the portal area though initially appears to be frozen but with slow and meticulous dissection, cystic duct and cystic artery could be controlled easily. Removal of gall bladder from fossa situated on under surface of liver was easy except more oozing and so three of our cases $(50 \%)$ required one unit of blood transfusion.

\section{Discussion}

The instigating factor for acute gall stone pancreatitis is transient or persistent obstruction of ampulla of vater by biliary calculi. Therefore the management of acute gall stone pancreatitis includes timely gall bladder surgery as well as evaluation and clearance of CBD. After severe pancreatitis, it is advisable to delay cholecystectomy until the local and systemic complications have resolved ${ }^{(6)}$. However, in mild gall stone pancreatitis the optimal time of cholecystectomy is still controversial. Cholecystectomy during the index admission, as soon as the patient has recovered from the attack of gall stone pancreatitis, has been recommended by the International association of pancreatology ${ }^{(7)}$, where as the American Gastroenterology Association ${ }^{(8)}$ recommend cholecystectomy within 2-4 weeks after discharge. Thus there is no unanimity among surgeons about appropriate timing of cholecystectomy.

Proponents of IC believe that acute pancreatitis induces oedema and more difficult dissection in patients who underwent cholecystectomy during the index admission. Thus, it potentially leads to more conversion to open surgery and more surgical complications such as bile duct injuries. However, contrary to above view in a recent study Sinha ${ }^{(9)}$ concluded that the difficulty in dissection of calot's triangle is more frequent in IC than EC during the index admission (42\% vs $12 \%, \mathrm{p}<0.001)$. Similarly the PONCHO trial ${ }^{(10)}$ in a systemic review demonstrated that cholecystectomy should probably be performed during index admission because an early procedure was not associated with an increased risk of complications, whereas interval cholecystectomy (after median 40 days) was associated with a biliary recurrence rate of $18 \%{ }^{(11)}$.

We are in full agreement to these authors ${ }^{(7,9,10,11)}$, that cholecystectomy should be performed during index admission in acute gall stone pancreatitis cases, as it not only prevents recurrence of further biliary events in these cases but is also a safe procedure. 


\begin{tabular}{|c|l|}
\hline S. No. & Intra-operative problems \\
\hline $\mathbf{1 .}$ & Hidden gall bladder, encased by omental and duodenal adhesions \\
\hline $\mathbf{2 .}$ & Adhesion of colon and omentum to anterior abdominal wall \\
\hline $\mathbf{3 .}$ & Areas of saponification seen spreaded all over omentum and peritoneum \\
\hline $\mathbf{4 .}$ & More friable and vascular tissues \\
\hline $\mathbf{5 .}$ & Plastering of portal area \\
\hline
\end{tabular}

Table 2: Intra-operative problems encountered

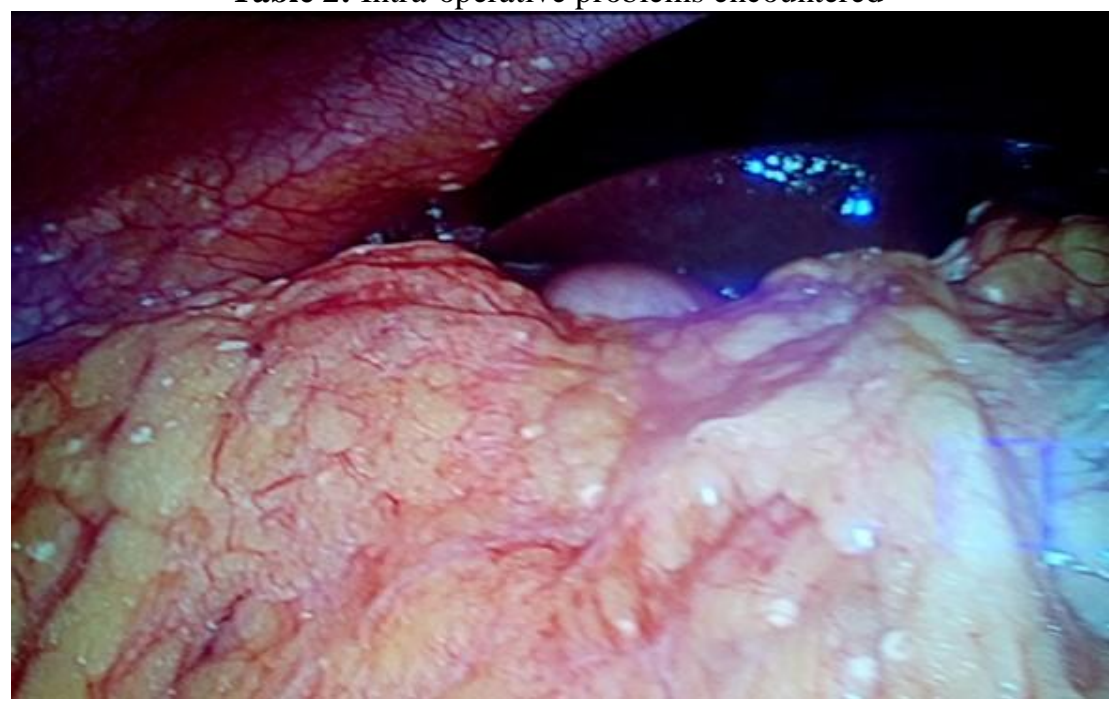

Fig.1 gall bladder hidden by omental wrapping

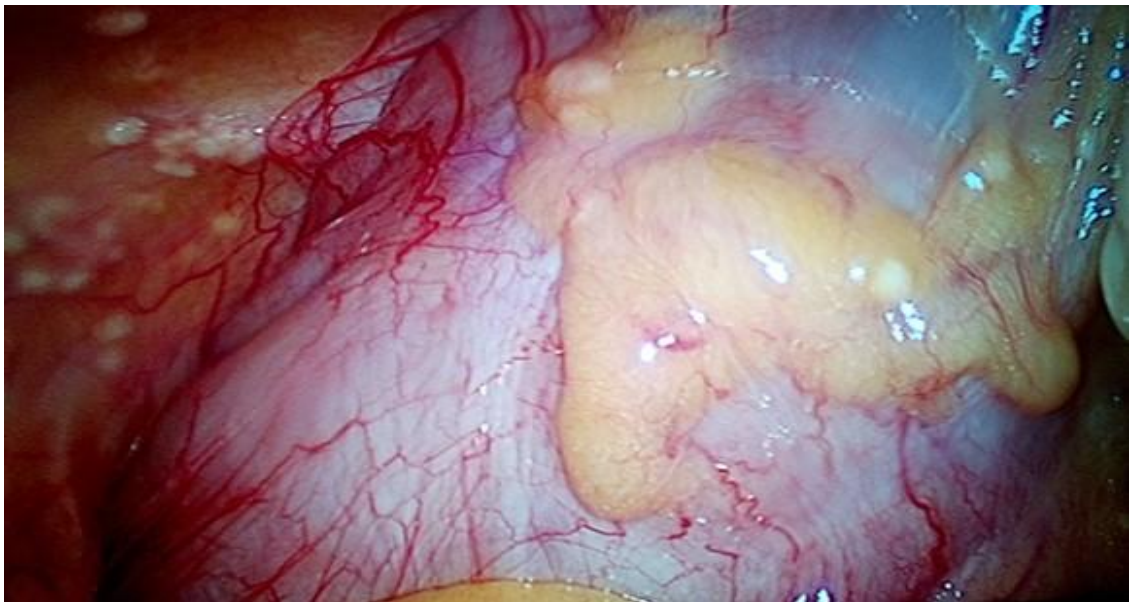

Fig.2 Showing areas of saponification spreaded all over peritoneal surface

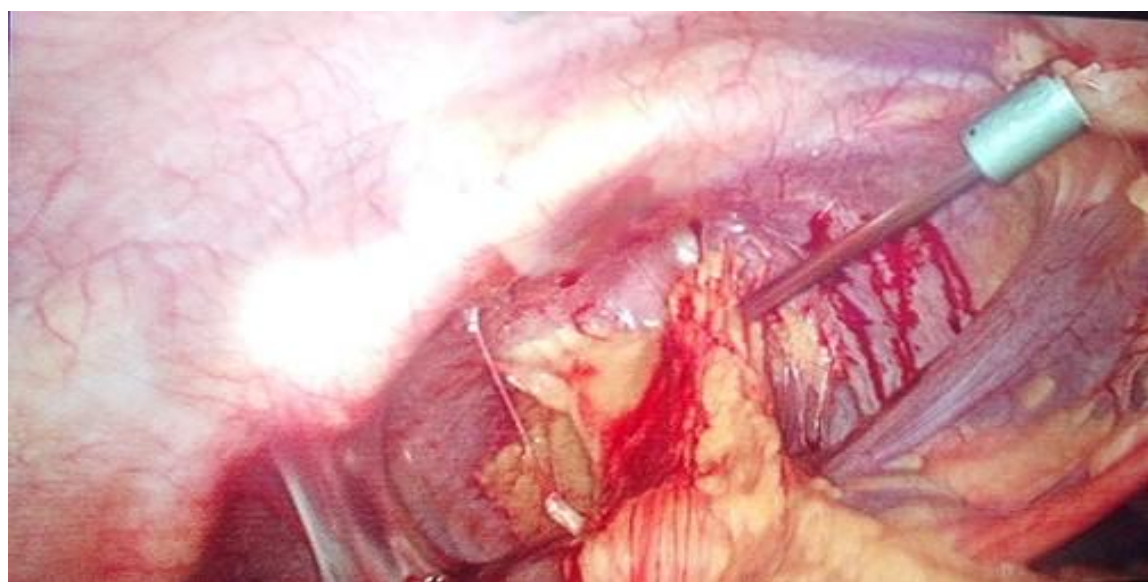

Fig.3 Showing adhesion of omentum to anterior abdominal wall 


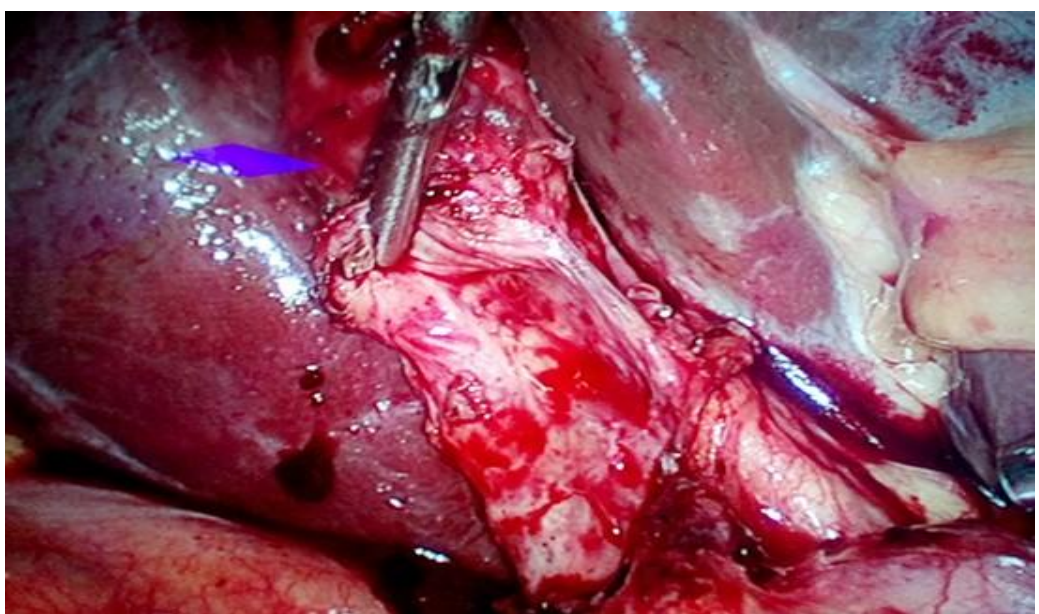

Fig.4 Showing plastering in portal region with more tissue vascularity, Rouvier's sulcus is also seen

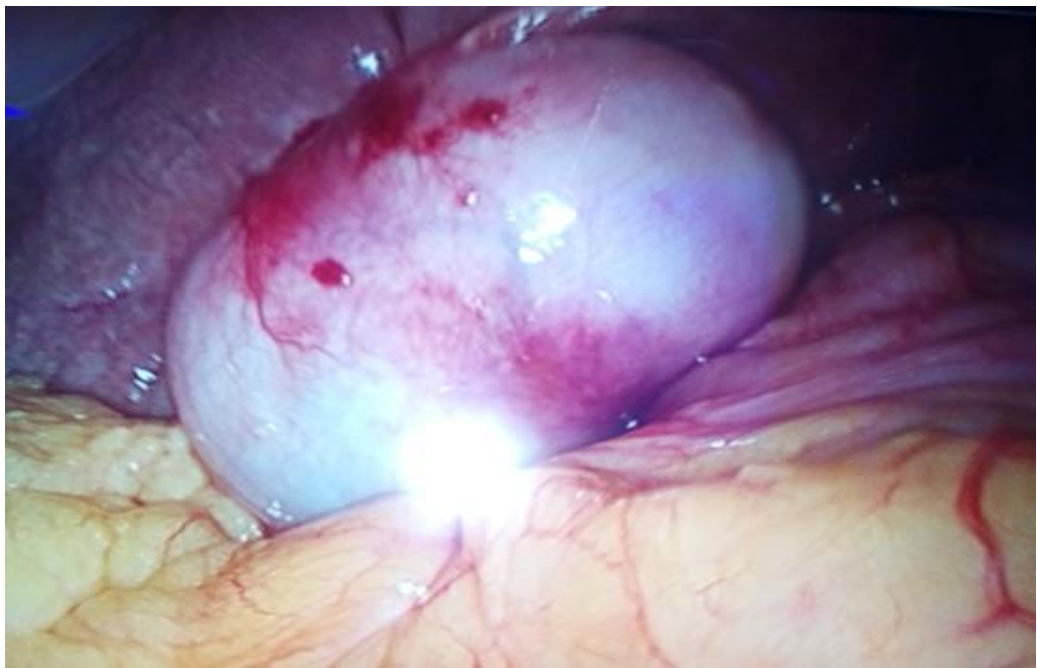

Fig. 5 Shows omental plastering with more tissue vascularity

In our experience of laparoscopic cholecystectomy in acute gall stone pancreatitis cases, intraoperative problems encountered (shown table 2) were - hidden gall bladder (Fig 1), Omental wrapping(Fig 5), omental adhesions(Fig3), plastering in portal area and increased tissue vascularity (Fig 4). However, all these problems overcome by slow, meticulous blunt metal suction tip dissection along with following all principles of safe lap cholecystectomy. Rouviere's sulcus view, all the time in our cases prevented dissection in wrong plain and hence none bile duct injury. Since tissues are oedematous and friable due to recent acute inflammation so a blunt dissection by suction tip is a safe way for lap cholecystectomy and we feel that suction tip is a marvellous instrument in this situation of inflamed, friable and oozy tissues in such cases.

In conclusion, early cholecystectomy (EC) for patients with acute gall stone pancreatitis was found to be a safe procedure when performed during the index admission, apart from its obvious advantages of significant reduction in the length of hospital stay as well as in the recurrent bilio-pancreatic gall stone related events.

\section{References}

[1]. Yada D, Lowenfels AB. Trends in the epidemiology of the first attack of acute pancreatitis: a systemic review. Pancreas 2006; 33 : 323-330

[2]. Hernandez V, Pascual I, Almela P et al. Recurrence of acute gall stone pancreatitis and relationship with cholecystectomy or endoscopic sphincterotomy. Am J Gastroenterol 2004; 99 : 2417-2423

[3]. Kasimu H, Jakai T, Quilong C, Jielile J. A brief evaluation for pre-estimating the severity of gall stone pancreatitis. J O P 2009; 10 : $147-151$.

[4]. Ranson J H, Rifkind KM, Roses DF, Fink S P, Eng K, Spencer F C. Prognostic sign's and the role of operative management in acute pancreatitis. Surg Gynecol Obstet 1974; 139: 69-81

[5]. Rouf Gul, Rayees Ahmad Dar, Riyaz Ahmad Sheikh, Nazir Ahmad Salroo, Adnan Rashid Matoo, and Sabiya Hamid Wani. : Comparison of early and delayed Laparoscopic cholecystectomy for acute cholecystitis : Experience from a single center. $\mathrm{N}$ Am $\mathrm{J}$ Med Sci. 2013 july; 5(7): 414-418. 
[6]. Nealon WH, Bawduniak J, Walser EM. Appropriate timing of cholecystectomy in patients who presents with moderate to severe gall stone associated acute pancreatitis with peripancreatic fluid collections. Ann Surg 2004; 239: 741-749.

[7]. Ulh W, Warshaw A, Imrie C, et al. I A P guidelines for the surgical management of acute pancreatitis. Pancreatology $2002 ; 2: 565$ 573

[8]. Forsmark CE, Baillie J. A G A Institute technical review on acute pancreatitis. Gastroenterology 2007; 132: 2022-2044.

[9]. Sinha R: Early Laparoscopic cholecystectomy in acute biliary pancreatitis: the optimal choice ? H P B (Oxord) 2008, 10: 332-335.

[10]. David W da Costa, Stefan A Bouwense, Nicolien J Schepers et al.: Same admission versus interval cholecystectomy for mild gall stone pancreatitis (PONCHO): a multi centre randomized controlled trial. The Lancet vol 386, no 10,000, P 1261-1268, 26 ${ }^{\mathrm{TH}}$ September 2015

[11]. Van Baal m c, Besselink M G, Bakker O J et al.: Dutch pancreatitis study group: timing of cholecystectomy after mild biliary pancreatitis: a systemic review. Ann Surg. 2012, $255: 860-866$ 